\title{
EJSBS
}

The European Journal of Social \&

Behavioural Science

ISSN: 2301-2218 (ONUINE)
OPEN ACCESS

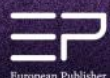

The European Journal of Social and Behavioural Sciences

EJSBS Volume XXX, Issue III (eISSN: 2301-2218)

\section{THE IMPACT OF E-LEARNING ON UNIVERSITY STUDENTS' LEARNING OF SPORT SKILL SUBJECTS DURING THE COVID-19 PANDEMIC}

\author{
Fatin Adira Murad ${ }^{\mathrm{a}}$, Azlan Ahmad Kamal ${ }^{\mathrm{a} *}$ \\ ${ }^{a}$ Universiti Teknologi MARA (UiTM), Selangor, Malaysia
}

\begin{abstract}
The Covid-19 pandemic has significantly altered the education system globally shutting down face-toface (f2f) learning in order to prevent the spread of the disease. The Malaysian government implemented Movement Control Order (MCO) starting in March 2020 creating a new norm for Malaysian citizens' working, educational and social environments. Work from Home (WFH) became part of the new norm for most working people with university students having no choice but to continue their education via Open and Distance Learning (ODL). Thus, this study investigates the impact of e-learning among university students studying sport skill subjects during this pandemic. An online survey was distributed to 152 students in their second to seventh semester majoring in Physical and Health Education to (1) investigate the well-being of students during online classes (2) identify the effectiveness of sport skill subjects learned online among the students and (3) study the relationship between online lectures and the effectiveness of learning sport skill subjects. A descriptive research design was used to describe the effects of e-learning among the students. The findings revealed that students did not suffer any psychological distress during online classes but indicated a lack of confidence in their capabilities in executing the skills in real life. No significant correlation was revealed between lecturing online and the effectiveness of learning sport skill subject learned among the students.
\end{abstract}

Keywords: Online learning, sport skill subjects, covid-19

C) 2021 Published by European Publisher. www.europeanpublisher.com

\footnotetext{
${ }^{*}$ Corresponding author.

E-mail address: azlankamal@uitm.edu.my
} 
https://doi.org/10.15405/ejsbs.300

eISSN: 2301-2218 / Corresponding Author: Azlan Ahmad Kamal

Selection \& Peer-review under responsibility of the Editors

\section{Introduction}

In Malaysia, several universities offer sports programmes for students to continue their studies in this area to tertiary level. One of these is Universiti Teknologi MARA (UITM) which offers undergraduate and postgraduate degrees in Physical and Health Education. Every university that offers such sports programmes have complete facilities for students to enable them to physically experience and learn the sport and health activities in order to teach these effectively when they become teachers. However, with the onset of the pandemic Covid-19, all educational activities had to shift to online platforms. According to Bibi and Jihan (2020), online learning has created many challenges for instructors while students have found themselves caught unawares in the online learning scenario (Rasheed, Abdul Aziz, Ahmed, \& Alia, 2020). These challengers require instructors to get out from their comfort zone and explore more technological means to ensure their students understand the topic being taught. The same goes for the students; they too need to face up to the challenges of studying from home (Chung, Subramaniam, \& Dass, 2020). Different paradigms of thinking about teaching online and studying from home need to be explored. The important question here is whether students are able to grasp the content meaningfully. This is especially so for subjects like sports science as, by their nature, these subjects involve physical activity and hands on teaching and learning within specific environments like a stadium or swimming pool; something that would be impossible to provide using an online mode. Thus, this study focuses on the impact that elearning has on students learning sport skill subjects.

\section{Problem Statement}

To be an effective Physical and Health Education (PHE) teacher, the individual needs to be an expert in every skill that has to be taught to their students. However, a study by Mohd Zairi, Azman, Nur Bahiyah, and Julia (2015) uncovered that the majority of students sampled in their study agreed that their PHE teacher only taught topics that were familiar to them. This highlights a concern that PHE teachers lack competence in teaching all the topics in PHE syllabus.

During this pandemic, all educational activities have moved online. While online learning is seen by many as an alternative route to continuing with the educational process, it nevertheless, has a psychological impact on students' mental health. Andi, Dwisona, and Lestari (2020)'s study found that online education did have psychological effects on Indonesian students during the pandemic. Their study found that in the first two weeks, students began to feel bored with the online class. Anxiety was another psychological byproduct of online learning especially with low-income students as students needed to 
https://doi.org/10.15405/ejsbs.300

eISSN: 2301-2218 / Corresponding Author: Azlan Ahmad Kamal

Selection \& Peer-review under responsibility of the Editors

constantly top up their data to participate in online learning. This would be a financial burden on students from the lower income group. Finally, emotional instability was apparent due to numerous assessments which students considered counterproductive. This concurs with a study done in Malaysia by Sundarasen et al. (2020) who studied anxiety among students in a Malaysian university during the Movement Control Order implemented by the Malaysian government between April and May 2020. The findings showed that almost a third of the students sampled suffered from moderate to severe levels of anxiety caused by online learning.

Another issue related to online learning is its efficacy. Anwar and Adnan (2020) posited that traditional face-to-face learning is more effective rather than online learning or distance education. This research compared the effectiveness between the online and face-to-face classes for university students and found that while the majority of students were happy with online classes, almost $80 \%$, even those who had appropriate internet facilities, felt traditional classes were more far more efficient compared to online learning. This finding is supported by Chung, Subramaniam, and Dass (2020) who, in their study, found that "more than half of the respondents indicated that if given a choice, they do not want to continue with online learning in the future" (n.p.). Chung et al. (2020)'s study is of particular importance to this current study as the student sample was similar to this study's sample being from the same university. Hence, the findings may be extrapolated to make acceptable generalisations about this particular population. Chung et al. Dass (2020)'s study also found that almost two thirds of diploma students faced a major challenge in grasping the subject content, in particular subjects like Economics which is a blend of both theoretical and quantitative knowledge. Interestingly, the study also found that gender and programme of study were significantly corelated with satisfaction with online leaning with female and degree students saying that they were more satisfied compared to male and diploma students respectively with online learning. With a sizeable sample of almost 400 students, these findings underscore the importance of establishing if e-learning is actually an effective mode for learning for university students because as this study's findings conclude "although they were generally ready for online learning, satisfied with online learning and their experience so far has been somewhat good, more than half of them would not want to continue with online learning if they had a choice, regardless of their gender and program level" (n.p.).

A final issue of importance related to e-learning is the availability of internet connection. Dhawan (2020) contends that the nature of online learning facilitates learning accessibility especially for students in rural and remote areas. However, this is disputed by the Malaysian experience through Chung, Subramaniam, and Dass (2020)'s study which found that more than half the students doing a degree programme stated that their major challenge 
https://doi.org/10.15405/ejsbs.300

eISSN: 2301-2218 / Corresponding Author: Azlan Ahmad Kamal

Selection \& Peer-review under responsibility of the Editors

was related to unstable internet connection. This problem specifically affected students in rural areas of East Malaysia during the MCO period. This is evidenced by the (in)famous episode concerning Veveonah Mosibin, an East Malaysian university student who had to climb a tree to attempt to complete a test during the MCO period (Lee, 2020). The digital divide between rural and urban students is severe in certain countries and cannot be ignored in any discussion about the effectiveness of online learning.

\section{Purpose of the Study}

With all these issues in mind, the researchers felt that an investigation into students' comprehension of learning content that is so dependent on hands on learning was warranted. This research focused on students majoring in Physical and Health Education to gather evidence on whether students' learning of sports skills through e-learning is sufficient to prepare them to become effective PHE teachers. Hence, the relationship between effectiveness of online lectures and the students' learning of sport skills was investigated. Additionally, the researchers also wanted to find out if the students were psychologically stable while engaging in e-learning.

\section{Research Objectives}

The study is based on the following objectives:

4.1 to investigate the psychological well-being of students learning during online classes.

4.2 to establish if learning sport skills online was effective.

4.3 to establish the relationship (if any) between lecturing online and the effectiveness of learning sport skills online.

\section{Research Questions}

5.1 Does online learning affect the psychological well-being of students studying sports skills?

5.2 Can sport skills be effectively learned through online learning?

5.3 What is the relationship between lecturing online and the effectiveness of learning sport skills online? 
https://doi.org/10.15405/ejsbs.300

eISSN: 2301-2218 / Corresponding Author: Azlan Ahmad Kamal

Selection \& Peer-review under responsibility of the Editors

\section{Research Methodology}

\subsection{Research design}

The researchers utilised a non-experimental, correlational quantitative research design which was considered suitable to gather the data necessary to describe the effects of elearning among second to seventh semester students majoring in Physical and Health Education in UITM. The research objectives necessitated a quantitative approach as this approach is the commonly used "to identify patterns and averages, make forecasts, assess causal relationships, and generalize findings to larger populations... and is widely used in the natural and social sciences" (Bhandari, 2020).

\subsection{Research population and sample}

The sampling was purposive in nature as the research focused on a particular group of students majoring in a single subject which, in this case, comprised the entire population of students from the second to seventh semesters majoring in Physical and Health Education of Universiti Teknologi MARA (UiTM) located in Puncak Alam in Malaysia. This particular location was selected because it is where the researchers work which facilitated the gathering of data needed to complete this study.

This university is unique as it caters to providing educational opportunities to the majority ethnic group in Malaysia which is the Bumiputera; literally translated to mean 'sons of the soil'. This refers to the Malay and other ethnic groups in East Malaysia who are historically considered the first settlers of Malaysia in comparison to the Chinese and Indian citizens whose forefathers were brought into the country by the British colonisers to work in the tin mines and rubber estates respectively. During the period when the country was colonized by the British, the majority of the Bumiputera ethnic group who lived in the rural areas were largely left out of the socio-economic loop. Hence, they were considered to be lagging socio-economically and educationally which served as the purpose of setting Institute Teknologi MARA in 1956 which was later upgraded to university status in 1999. So, demographically, the only ethnic group participating in this study is Bumiputera. No other demographic elements were considered in the investigation as this was an exploratory study focussing only on establishing if sports skills could be effectively learned in an online environment and if learning such skills online had any psychological consequences on students' well-being. 


\subsection{Research instrument}

Since this study used a quantitative approach, the research instrument utilised was a questionnaire which was distributed to all the second to seventh semester students majoring in Physical and Health Education in UiTM, Puncak Alam campus. This questionnaire was constructed by adapting and modifying four validated questionnaires used in previous studies (see Table 1). Some of the questions from the original questionnaires were omitted or adapted and new items were added in line with the feedback obtained from the pilot test.

Table 1. Questionnaires used to create the final questionnaire for this study

\begin{tabular}{|c|c|c|}
\hline & Name of Questionnaire & Name of The Developer \\
\hline 1 & $\begin{array}{l}\text { Development and Validation of the Online Student } \\
\text { Connectedness Survey (OSCS) }\end{array}$ & $\begin{array}{l}\text { Bolliger, D.U. \& Fethi A. I. } \\
(2012)\end{array}$ \\
\hline 2 & Sources of Sport Confidence Questionnaire (SSCQ) & $\begin{array}{l}\text { Vealey, R.S., Garner-Holman, } \\
\text { M., Hayashi, S.W., \& } \\
\text { Giacobbi, P. (1998) }\end{array}$ \\
\hline 3 & Athlete Sport Competence Inventory & $\begin{array}{l}\text { Causgrove Dunn, J., Dunn, J. } \\
\text { G. H. \& Bayduza, A., (2007) }\end{array}$ \\
\hline 4 & Sport Confidence Inventory & $\begin{array}{l}\text { Cox, R. H., Martens, M. P. \& } \\
\text { Russell, W. D (2003) }\end{array}$ \\
\hline
\end{tabular}

A pilot test was conducted to ensure the reliability and validity of the final modified questionnaire. 30 respondents randomly selected from among the targeted population comprising Physical and Health Education students in UiTM Puncak Alam were involved in the pilot test. The Cronbach values show that all the items were acceptable (see Table 2).

Table 2. Pilot Test

\begin{tabular}{lll}
\hline Variables & Number of Item & Cronbach's Alpha \\
\hline Students' well-being & 8 & .884 \\
\hline Lecturing Online & 6 & .880 \\
\hline Effectiveness of Online Learning & 10 & .967 \\
\hline
\end{tabular}

The final questionnaire consisted of 24 items; 8 items to answer Research Question 1 related to students' psychological well-being; 10 items to answer Research Question 2 on the effectiveness of online learning; and, 6 items to answer Research Question 3 on online lectures.

The data was analyzed using the Statistical Package for the Social Sciences (SPSS). Descriptive analysis was used to interpret the means and standard deviations for the first and second research questions, while Pearson correlation was used to identify the possible 
https://doi.org/10.15405/ejsbs.300

eISSN: 2301-2218 / Corresponding Author: Azlan Ahmad Kamal

Selection \& Peer-review under responsibility of the Editors

relationship between the online lectures and the effectiveness of learning sport skills. To answer the research questions, the researchers employed two procedures as showed in Table 3.

Table 3. Data Analysis procedures

\begin{tabular}{ll}
\hline Research Question & Statistical procedures used \\
\hline $\begin{array}{l}\text { Does online learning affect the psychological well-being } \\
\text { of students studying sports skills? }\end{array}$ & Descriptive Analysis \\
& -Mean, Standard Deviation \\
\hline Can sport skills be effectively learned through online & Descriptive Analysis \\
learning? & -Mean, Standard Deviation \\
\hline $\begin{array}{l}\text { What is the relationship between lecturing online and the } \\
\text { effectiveness of learning sport skills online? }\end{array}$ & Correlation \\
\hline
\end{tabular}

\section{Findings and Discussion}

The findings are discussed by providing the data analysis for each research question for easy comprehension of the evidence. Tables showing the analysis of all the questionnaire items dedicated to the related Research Question are provided.

\subsection{Does online learning affect students' psychological well-being? (Research Question 1)}

Table 4. Descriptive statistics for psychological well-being of students during online classes

\begin{tabular}{|c|c|c|c|}
\hline & $\mathrm{N}$ & Mean & Std. Deviation \\
\hline If I need to, I will ask for help from my classmates. & 152 & 4.49 & .620 \\
\hline $\begin{array}{l}\text { I feel comfortable expressing my opinions and } \\
\text { feelings in online classes. }\end{array}$ & 152 & 3.58 & .973 \\
\hline $\begin{array}{l}\text { I feel comfortable introducing myself in online } \\
\text { classes. }\end{array}$ & 152 & 3.69 & .886 \\
\hline I can effectively communicate in online classes. & 152 & 3.45 & 968 \\
\hline $\begin{array}{l}\text { I feel comfortable asking other students in online } \\
\text { classes for help. }\end{array}$ & 152 & 3.65 & .998 \\
\hline $\begin{array}{l}\text { I have no difficulties with expressing my thoughts in } \\
\text { online classes. }\end{array}$ & 152 & 3.37 & 1.028 \\
\hline $\begin{array}{l}\text { I feel my lecturers have created a safe online class } \\
\text { environment in which I can freely express myself. }\end{array}$ & 152 & 3.86 & .846 \\
\hline $\begin{array}{l}\text { I feel comfortable in the online class environment } \\
\text { provided by my programme. }\end{array}$ & 152 & 3.57 & 1.034 \\
\hline Valid N (listwise) & 152 & & \\
\hline
\end{tabular}


Based on the findings in Table 4, the highest mean among the 8 items in the questionnaire is for the item "If I need to, I will ask for help from my classmates" with mean= 4.49 and SD .620 while the lowest rating was for the item "I have no difficulty with expressing my thoughts in online learning class" with the mean $=3.37$ and $\mathrm{SD}=1.028$. Due to the nature of this sample, all being from the same ethnic group and culturally similar, they have no reservations asking help from their classmates during online classes. Chung, Noor and Mathew (2020)'s study also found that students like to share ideas with their friends and improve themselves while learning online. These findings show that students are comfortable asking help from their friends during online classes. In this current study, students indicated that they faced problems expressing their opinions during online classes. Hence, lecturers should attempt to create an approachable and non-hostile online environment that encourages students to actively participate in class. Jones and Issroff, (2005) stated that students need to feel safe in the online environment and community. Besides, Farhan (2020) stated that students faced difficulties in online classes when they do not understand the content of the lecture slides or other teaching materials prepared by the lecturers but are reluctant to ask questions during the class. Unlike the traditional face-to-face classes, lecturers could use students' body language signals to find out if they could not comprehend the lesson and respond accordingly. Reading body language cues are not possible in e-learning; hence, the lecturers need to be more creative in conducting the classes online in order to engage the students' attention and implement a two-way communication during the online class. This would help students to ask questions, express their thoughts and feelings during the class. However, overall, the findings show that online learning does not affect students' psychological well-being as all the mean scores exceed 3.00 meaning that the students in this study perceive their psychological well-being to be intact during online classes.

\subsection{Can sport skills be effectively learned through online learning? (Research Question 2)}

Table 5. Descriptive statistics for the Effectiveness of Sport Skills Subject Learned through Online Learning

\begin{tabular}{llll}
\hline & $\mathrm{N}$ & Mean & Std. Deviation \\
\hline I am able to master a new sport skill after online learning. & 152 & 3.41 & 1.006 \\
$\begin{array}{l}\text { I am able to improve my performance on skills through online } \\
\text { learning. }\end{array}$ & 152 & 3.28 & 1.005 \\
$\begin{array}{l}\text { I am able to increase the number of skills I can master through } \\
\text { online learning. }\end{array}$ & 3.39 & .907 \\
$\begin{array}{l}\text { I am able to develop and improve new skills through online } \\
\text { learning. }\end{array}$ & 152 & 3.44 & .919 \\
$\begin{array}{l}\text { I am able to improve my sport skills through online learning. } \\
152\end{array}$ & 3.34 & .898
\end{tabular}


https://doi.org/10.15405/ejsbs.300

eISSN: 2301-2218 / Corresponding Author: Azlan Ahmad Kamal

Selection \& Peer-review under responsibility of the Editors

I can execute technical skills well. (e.g., shooting, passing, blocking, etc.)

I can execute tactical skills well (e.g., decision-making, $\quad \begin{array}{lll}152 & 3.30 & .982\end{array}$ reading the play, strategy, etc.)

I can execute physical skills well. (e.g., strength, speed, agility, $152 \quad 3.27 \quad 1.016$ endurance, etc.)

I am confident I can meet challenges of learning the skill $\quad \begin{array}{lll}152 & 3.68 & 1.006\end{array}$ online.

$\begin{array}{llll}\text { I am confident about executing the sport skills well. } & 152 & 3.59 & 1.051\end{array}$ Valid N (listwise)

Table 7.2 shows the data analysis of the responses to the 10 items in the questionnaire related to this research question. The highest rating was for the item "I am confident in meeting the challenge of learning the skill online (mean=3.68, SD 1.006) while the lowest rating was for the item "I can execute physical skills well" with mean=3.27 and $\mathrm{SD}=1.016$. Although the students stated that they are confident in meeting the challenges of learning the skill online they were not so confident in execute the skills physically. This shows that although they feel confident in meeting the challenges of learning the skill online, when it comes to the actual execution, they lack confidence. This means that their online learning confidence does not match their expectation of skills execution in actual physical settings. This also means that although the online classes may seem effective, students lack confidence in the actual execution of the sport skill after the online class. This can be considered a natural progression in the learning of skills similar to learning to drive a car or baking a cake where we feel we understand what to do when the instructor is driving or baking but it is a different story when we have to drive or bake on our own.

Another thing to notice in this analysis is that all the responses are hovering in the middle range of $3.27-3.44$ as to their ability to master and execute the skills. The only 2 responses that show slightly higher mean scores are those that relate to students' confidence levels with $3.59-3.68$. So, it seems that the students are confident that they have learnt the skills in online classes, but in actual fact, they are unsure that they are capable of actually executing the skills in physical settings as indicated by the lower mean scores. The absence of higher mean scores indicate the students' acceptance of their own capabilities of executing skills learnt online with actual conditions in the real world. It is a worrying but good indicator of the gap between learning sports skills online and executing these skills in the real world. This aligns with Levy (2007) who posited that students need to feel able and confident in their abilities to learn and take something away from the class for them to feel content with their learning experiences; hence, they would be at a lower risk of dropping out. For a subject like sports science, students are basically learning the skills on their own during online classes, 
https://doi.org/10.15405/ejsbs.300

eISSN: 2301-2218 / Corresponding Author: Azlan Ahmad Kamal

Selection \& Peer-review under responsibility of the Editors

without their classmates or lecturer close by to guide or correct them. Thus, the students would not know whether they are executing the skills using the correct technique which would definitely create a sense that they may not be executing the skill correctly. This would naturally lead to a loss of confidence in their capabilities. This is supported by Hyun and Wi (2020) who found that students face problems in physical education in online classes due to limited environmental conditions and educational content, which leads to lack of effectiveness and quality of the sports skill learned. The researchers believe that this is a natural consequence of trying to learn a skill-based subject online. So, for the second research question of whether sport skills be effectively learned through online learning, it appears that the students are not highly confident that they can.

7.3. What is the relationship between lecturing online and the effectiveness of learning sport skills online? (Research question 3)

Table 6. Correlation between Lecturing Online and the Effectiveness of Sport Skill

\begin{tabular}{llll}
\hline & & Role & Effectiveness \\
\hline Role & Pearson Correlation & 1 & $.408^{* *}$ \\
& Sig. (2-tailed) & & .000 \\
& $\mathrm{~N}$ & 152 & 152 \\
\hline Effectiveness & Pearson Correlation & $.408^{* *}$ & 1 \\
& Sig. (2-tailed) & .000 & \\
& $\mathrm{~N}$ & 152 & 152 \\
\hline
\end{tabular}

A Pearson correlation test was conducted to determine the relationship between the role of lecturer and the effectiveness of learning sport skills online. The analysis found that $r=.408$ and $\mathrm{p}$-value $=.000$, where $\mathrm{p}$-value is smaller than 0.01 showing no significant relationship between the lecturing online and the effectiveness of sport skill subject learned among students. This shows that, from the students' perspective, online lectures have no bearing on the effectiveness of learning sports skills online. This is a positive finding that online learning supports independent learning as students can learn such skills on their own by sourcing videos related to the sport skills they need to learn.

The success of e-learning depends on the understanding of the students that they are part of the system according to Nursyahidah, Zazaleena, Zalina, and Norafizal (2011). The effectiveness of online learning is dependent on students being responsible for their own learning. The nature of online learning is such that students need to motivate themselves and remain motivated during the classes. However, its must also be noted that effective e-learning is predicated on technological availability in terms of having the gadgets like laptops and 
https://doi.org/10.15405/ejsbs.300

eISSN: 2301-2218 / Corresponding Author: Azlan Ahmad Kamal

Selection \& Peer-review under responsibility of the Editors

smartphones as well as internet connectivity. This is a serious issue for certain socio-economic groups as already stated previously. Accessibility, according to students, is the main impeding factor on the effectiveness of online learning during this pandemic (Mohamad Faizal, Muhammad, \& Basri, 2020). Their research found that the difficulties for students during online learning were expensive data plans, and limitations of internet access and devices. This is supported by Adedoyin and Soykan (2020) who found that internet and devices were essential for students and academicians during online learning because without these, it is impossible to conduct or attend online classes. This shows that online learning has its limitations especially when students lack the technology required for effective online learning. Once this challenge is overcome however, online learning can be an effective alternative learning mode as Bryant and Bates (2015) found a strong positive correlation between social interaction, sense of community, and their roles in achieving success in online learning. Jackson, Jones, and Rodriguez (2010)'s study which explored students' perceptions of faculty factors showed that when teachers were viewed as providing guidance and clear goals, students were more pleased with their online classes. This could be understood to mean that the lecturer needs to ensure that the online lectures are as clear as possible for students to understand, instructions for tasks and assessments are very clear and aligned to online parameters, provide multiple opportunities for students to clarify their doubts and the classroom discourse is more participative in order to ensure the effectiveness of online learning

\section{Conclusions, Implications and Recommendations}

In conclusion, online learning, despite its advantages of anytime anywhere learning, is not the best platform to teach skill-based subjects for both lecturers and the students. This study shows that, in spite of their confidence during online classes, students admitted to a lack of confidence in executing the skills in real world settings.

Studies like that of Andi, Dwisona, and Lestari (2020)'s and Sundarasen et al. (2020)'s have shown the psychological distress suffered by students in online settings while studies like Chung, Subramaniam, and Dass (2020)'s found that students still preferred traditional classes. While this current study did not specifically address this question, it can be assumed that, given the choice, this set of students would prefer traditional classes since they can actually learn and practice the skills in the stadium, field, swimming pool and other appropriate sports venues. It is not difficult to comprehend that online learning no matter no technologically superior can replicate the authenticity of these environments in the development of sports skills for students. 
These results contradict the views of proponents of e-learning who claim that e-learning is the way to go. Perhaps, online learning may be suitable for certain subjects which are more theoretical or abstract in nature like philosophy or ethics, but with the requirements for skillbased subjects like Sports Science, Dance and Theatre, the findings from this study are not surprising. The implications for lecturers and instructional design for such subjects are deep and worrying as these findings reveal that effective learning is not occurring through online classes. This is a particularly deep concern as these students will be PHE teachers in future. Their lack of confidence in mastery of these skills will affect their teaching and their students' learning as confirmed by Mohd Zairi, Azman, Nur Bahiyah, and Julia (2015) who found that school students stated that their PHE teachers only taught skills they were familiar with. This highlights another worrying implication as to whether the school PHE syllabi are being properly covered in schools, in this case. Students who have been exposed to sport skills via online learning may fall into this category once they become teachers since they have already expressed their lack of confidence in demonstrating skills in real life situations.

Although this study did not report any severe psychological distress from the students, other studies have reported psychological distress of students engaged in online learning from moderate to severe anxiety being reported (Sundarasen et al. 2020). Again, this is not surprising as students who have been used to the traditional learning environments now suddenly forced into silo like online learning which may not suit their learning style, more so for subjects like sports science which are more physical and team oriented in nature. In the case of this study, students' perceptions of psychological wellness during online classes may be authentic or they may have been a consequence of response bias originating from the respondents themselves resulting from satisficing (Bogner \& Landrock, 2016) who contend that

"Respondents who have a tendency to satisfice when answering questions are motivated by a desire to reduce their cognitive effort. This results in response biases such as acquiescence or moderacy bias. In the case of socially desirable responding, respondents orient themselves towards social norms in order to answer in the way in which they assume that the interviewer expects them to answer" (p. 2).

This means that the students in this survey may have unwittingly responded in a way which they believed was how the researchers would have wanted them to respond so as not to "offend" the researchers who were also their lecturers. There is also the possibility that

"Respondents who display satisficing behaviour interpret the question in a merely superficial way and report the first answer that comes into their heads or that appears to them to be plausible (Krosnick, Nayaran, \& Smith, 1996). This may give rise to response bias, for 
https://doi.org/10.15405/ejsbs.300

eISSN: 2301-2218 / Corresponding Author: Azlan Ahmad Kamal

Selection \& Peer-review under responsibility of the Editors

example when respondents choose the middle response category irrespective of the content of the question in order to simplify the cognitive process" (p. 1).

This would account for the majority of the responses for this section of the questionnaire ranging from $3.45-3.86$. This may explain the responses of the students in this study who appear to exhibit no psychological distress whatsoever during their online classes, which contradicts the findings of many other studies. Taken at face value, however, it is a positive and encouraging indication that students majoring in Physical and Health Education are well balanced in terms of their own physical and psychological wellness.

However, having said that, the situation right now warrants that all educational activities proceed on online platforms. Hence, there is no choice but to do all that needs to be done to ensure that teaching and learning be conducted as effectively as possible, given the constraints for subjects like Sports Science. Lecturers need to understand not only students' educational needs but also cater to their psychological needs as the research has shown. Students need to be constantly motivated by lecturers who must alter their teaching styles and materials to suit the online environment. Teaching of skills online can be challenging, but there are many virtual technologies that can make skill learning more interactive, enjoyable and effective for the students learning sports skills. According to Farley, Spenser and Baudinet (2019),

"The last decade, notably the past two years, have seen significant advancements in virtual reality (VR) technology, especially within the development of $3 \mathrm{D}$ and $360^{\circ}$ virtual environments.... Sport training can now take full advantage of the improved quality of operating systems and as a result, VR provides visual simulations and immersive, interactive environments. VR technology is becoming more popular with evident influence on collecting various physiological aspects, identifying and improving sensorimotor capabilities, replicating competition and environment situations where reaction time is critical, and developing skill acquisition" (n.p.)

Lecturers need to understand that they cannot teach online the same way they did in traditional classrooms. There is a sports ministry in Malaysia; the faculty and curriculum developers may want to consider how to rope in the ministry into creating engaging learning materials for the students in tandem with the Ministry. Perhaps, talks with ministry officials, trainers and coaches can be slotted as guest lecturers. Listening to and communicating with real life coaches and trainers and athletes would definitely motivate any students learning sports skills.

Students' technological needs like connectivity, access, devices and ICT capabilities must be met by the government and related agencies to ensure continuity in learning during 
https://doi.org/10.15405/ejsbs.300

eISSN: 2301-2218 / Corresponding Author: Azlan Ahmad Kamal

Selection \& Peer-review under responsibility of the Editors

this pandemic. Students cannot totally be dependent on lecturers' spoon feeding them; they need to take the initiative to engage in independent and outside the classroom learning to master the skills since they have no access to meeting lecturers, friends or venues during this pandemic. Students can form learning groups on their own with a senior/s as mentors and learn to master the skills on their own. They can utilise social media to contact well-known athletes and ask them questions on skills building. Lecturers can help set up such networking which would be helpful even after the students graduate. These are a few ways that students can engage in independent learning during this period.

Online learning has its advantages and disadvantages; it is up to the individual how he/ she wishes to react to the situation. Do we keep blaming the situation or take control of it? That is the question that both the lecturers and students need to answer in their own way.

\section{Acknowledgements}

The author(s) declare that there is no conflict of interest.

\section{References}

Adedoyin, O., \& Soykan, E. (2020). Covid-19 pandemic and online learning: the challenges and opportunities, Interactive Learning Environments, 1-13. https://doi.org/10.1080/10494820.2020.1813180

Andi, W. I., Dwisona, D., \& Lestari, M. (2020). Psychological Impacts of Students on Online Learning During the Pandemic COVID-19. KONSELI: Jurnal Bimbingan dan Konseling [Counselling and Guidance Journal], 7, 53-60. https://doi.org/10.24042/kons.v7i1.6389

Anwar, K., \& Adnan, M. (2020). Online learning amid the COVID-19 pandemic: Students' perspectives. Journal of Pedagogical Research. 1. 45-51. https://doi.org/10.33902/JPSP.2020261309

Bhandari, P. (2020). An Introduction to Quantitative Research. Scribbr. https://www.scribbr.com/methodology/quantitative-research/

Bibi Noraini Mohd Yusuf \& Jihan Ahmad. (2020). Are we Prepared Enough? A Case Study of Challenges in Online Learning In A Private Higher Learning Institution During The Covid-19 Outbreaks. Advances in Social Sciences Research Journal, 7(5), 205-212. https://doi.org/10.14738/assrj.75.8211

Bogner, K., \& Landrock, U. (2016). Response Biases in Standardised Surveys. GESIS Survey Guidelines. Mannheim, Germany: GESIS - Leibniz Institute for the Social Sciences. https://doi.org/10.15465/gesis-sg_en_016

Bolliger, D. U., \& Fethi, A. I. (1998). Development and validation of the Online Student Connectedness Survey (OSCS). International Review of Research in Open and Distance-Learning, 14(3), 1492-3831. https://doi.org/10.19173/irrodl.v13i3.1171

Bryant, J., \& Bates, A. (2015). Creating a Constructivist Online Instructional Environment. TechTrends, 59. https://doi.org/10.1007/s11528-015-0834-1 
Cox, R. H., Martens, M. P., \& Russell, W. D. (2003). Measuring Anxiety in Athletics: The Revised Competitive State Anxiety Inventory-2. Journal of Sport \& Exercise Psychology, 25(4), 519-533. https://doi.org/10.1123/jsep.25.4.519

Chung, E., Noor, N. M., \& Mathew, V. N. (2020). Are You Ready? An Assessment of Online Learning Readiness among University Students. International Journal of Academic Research in Progressive Education and Development, 9(1), 301-317 https://doi.org/10.6007/IJARPED/v9-i4/8177

Chung, E., Subramaniam, G., \& Dass, L. C. (2020). Online Learning Readiness Among University Students in Malaysia Amidst Covid-19. Asian Journal of University Education. 16(2). 46-58. https://doi.org/10.24191/ajue.v16i2.10294

Causgrove Dunn, J., Dunn, J. G. H., \& Bayduza, A. (2007). Perceived athletic competence, sociometric status, and loneliness in elementary school children. Journal of Sport Behavior, 30, 249-269. https://www.researchgate.net/publication/273379946

Dhawan, S. (2020). Online Learning: A Panacea in the Time of COVID-19 Crisis. Journal of Educational Technology $\quad$ Systems, $\quad 49(1), \quad 5-22$. https://doi.org/10.1177/0047239520934018

Farhan Kamarulzaman (2020, December 15). Tambah baik sistem pendidikan sesuai norma baharu [Improving the educational system to suit the new norm] Berita Harian [Daily News]. https://www.bharian.com.my/rencana/komentar/2020/12/765191/tambahbaik-sistem-pendidikan-sesuai-norma-baharu

Farley, O. R. L., Spenser, K., \& Baudinet, L. (2019). Virtual reality in sports coaching, skill acquisition and application to surfing: A review. Journal of Human Sport and Exercise 15(3), 1 -14. https://doi.org/10.14198/jhse.2020.153.06

Gall, M. D., Gall, J. P., \& Borg, W. R. (2007). Educational research: An introduction (8th ed.). Boston: Pearson.

Hyun-Chul Jeong \& Wi-Young So. (2020). Difficulties of Online Physical Education Classes in Middle and High School and an Efficient Operation Plan to Address Them. International journal of environmental research and public health, 17. https://doi.org/10.3390/ijerph17197279

Jackson, L. C., Jones, S. J., \& Rodriguez, R. C. (2010). Faculty actions that result in student satisfaction in online courses. Journal of Asynchronous Learning Networks, 14, 78-96. https://doi.org/10.24059/OLJ.V14I4.129

Jones A., \& Issroff, K. (2005). Learning technologies: Affective and social issues in computer-supported collaborative learning. Comput Educ., 44, 395-408 https://doi.org/10.1016/j.compedu.2004.04.004

Lee, S. (2020, June 16). Sabah student stays overnight in tree to get better Internet connection for online university exams. The Star. https://www.thestar.com.my/news/nation/2020/06/16/sabah-uni-student-staysovernight-in-tree-to-get-better-internet-connection-for-online-exams

Levy, Y. (2007). Comparing dropouts and persistence in e-learning courses. Computers \& Education, 48(2), 185-204. https://doi.org/10.1016/j.compedu.2004.12.004

Mohamad Faizal Ramli, Muhammad Majid \& Basri Badyalina (2020). Impeding Factors Towards the Effectiveness of Online Learning During Covid-19 Pandemic among Social Sciences Students. International Journal of Learning and Development, 10(4), 37-4, https://doi.org/10.5296/ijld.v10i4.17921 
Mohd Zairi Hussain, Azman Hassan, Nur Bahiyah Abdul Wahab \& Julia Jantan (2015). Determining Teaching Effectiveness for Physical Education Teacher. Procedia - Social and Behavioral Sciences, 172, 733-740. https://doi.org/10.1016/j.sbspro.2015.01.426

Nursyahidah Alias, Zazaleena Zakariaha, Nor Zalina Ismail, \& Mohd Norafizal Abd Aziz (2012). E-Learning Successful Elements for Higher Learning Institution in Malaysia Procedia - Social and Behavioral Sciences, 67, 484 - 489. https://doi.org/10.1016/j.sbspro.2012.11.353

Rasheed Mohammad Nassr, Abdulaziz Aborujilah, Danah, Ahmed Aldossary \& Alia Ahmed Abdullah Aldossary (2020). Understanding Education Difficulty During COVID-19 Lockdown: Reports on Malaysian University Students' Experience. IEEE Access, 8, 186939-186950. https://doi.org/10.1109/ACCESS.2020.3029967

Sundarasen, S., Chinna, K., Kamaludin, K.... Sukayt, A. (2020). Psychological Impact of COVID-19 and Lockdown among University Students in Malaysia: Implications and Policy Recommendations. Int. J. Environ. Res. Public Health 2020, 17, 6206. https://doi.org/10.3390/ijerph17176206

Vealey, R. S., Garner-Holman, M., Hayashi, S. W., \& Giacobbi, P. (1998). Sources of SportConfidence: Conceptualization and Instrument Development. Journal of Sport an Exercise Psychology, 20(1), 54-80. https://doi.org/10.1123/JSEP.20.1.54 